\title{
Spraying Leaves of Pear Nursery Trees with Urea and Copper Ethylenediaminetetraacetic Acid Alters Tree Nitrogen Concentration without Influencing Tree Susceptibility to Phytophthora syringae
}

\author{
S. Laywisadkul ${ }^{1,3}$, C.F. Scagel ${ }^{2}$, L.H. Fuchigami ${ }^{1}$, and \\ R.G. Linderman ${ }^{2}$
}

AdDitional Index wORDs. defoliant, fertilizer, phosphonate, Pyrus communis

SUMMARY. Recent field observations by growers suggest that increased nitrogen $(\mathrm{N})$ content in nursery trees resulting from foliar sprays with urea in the autumn increases tree susceptibility to infection by Phytophthora syringae. We investigated the effects of soil $\mathrm{N}$ availability and spraying pear (Pyrus communis 'OHF 97') trees with combinations of urea, chelated copper ethylenediaminetetraacetic acid (CuEDTA), and phosphonate-containing fungicides on stem $\mathrm{N}$ concentration and susceptibility to infection by $P$. syringae. Increasing soil $\mathrm{N}$ availability increased susceptibility to $P$. syringae and increased $\mathrm{N}$ and amino acid concentration in stems. Spraying trees with urea in the autumn increased concentrations of $\mathrm{N}$ and amino acids in stems and had no significant effect on tree susceptibility when stems were inoculated with $P$. syringae before or after urea sprays. Spraying trees with CuEDTA decreased stem $\mathrm{N}$ concentrations and had no significant influence on tree susceptibility to $P$. syringae when stems were inoculated before or after CuEDTA sprays. These results suggest the relationship between tree susceptibility to $P$. syringae and tree $\mathrm{N}$ concentration may be specific to the form of $\mathrm{N}$, delivery method, or timing of $\mathrm{N}$ applications. Trees had higher $\mathbf{N}$ concentrations in stems in November than in October and were more susceptible to P. syringae when inoculated in November, suggesting that environmental factors and increasing tree dormancy may be responsible for changes in susceptibility to the pathogen. Spraying trees with fungicides containing fosetyl-aluminum in October or November decreased tree susceptibility to $P$. syringae. The effects of fungicides containing fosetyl-aluminum on susceptibility were similar regardless of whether trees were sprayed or not with urea or CuEDTA, suggesting that these fungicides can be used in combination with urea or CuEDTA sprays for reducing disease severity caused by $P$. syringae without impacting growers' objective of increasing tree $\mathrm{N}$ content with urea or enhancing early defoliation with CuEDTA.

$\mathrm{D}$ iseases caused by species of Phytophthora are responsible for significant economic losses on a wide range of host plants, including pear (Erwin and Ribeiro, 1996; Harris, 1979; Wormald, 1919). Disease caused by Phytophthora syringae occurs during the winter in nursery stock in the Pacific northwest region

This work was funded in part by the U.S. Department of Agriculture-Agricultural Research Service, Northwest Center for Nursery Crop Research

Mention of a trademark, proprietary product, or vendor does not constitute a guarantee or warranty of the product by the U.S. Department of Agriculture and does not imply its approval to the exclusion of other products or vendors that also may be suitable.

${ }^{1}$ Department of Horticulture, Oregon State University, Corvallis, OR 97331

${ }^{2}$ U.S. Department of Agriculture, Agricultural Research Service, Horticultural Crops Research Unit, 3420 NW Orchard Avenue, Corvallis, OR 97330

${ }^{3}$ Corresponding author. E-mail: srisangwan@gmail.com. of the United States (PNW), especially on trees that are harvested and stored in coolers or in outdoor sawdust beds (Erwin and Ribeiro, 1996; Pscheidt and Ocamb, 2002; Tidball and Linderman, 1990). The fungus spreads via splash dispersal of inoculum from soil to leaves, stems, and fruit (Ristaino and Gumpertz, 2000; Upstone, 1978), and infects trees through wounds on stems caused by handling or pruning or through leaves and leaf scars (Bostock and Doster, 1985; De Bruyn, 1924). In nursery stock, dark, sunken cankers occur on stems, and in severe cases, the stem is girdled (Erwin and Ribeiro, 1996; Young and Milbrath, 1959).

Most pear varieties in the PNW are grafted on selected rootstock clonally propagated in nurseries and defoliated before harvesting and cold storage, similar to production practices used for many other deciduous nursery trees (Frecon, 1982). Methods used for defoliation include manual or mechanical removal of leaves and the use of chemical sprays [e.g., chelated copper ethylenediaminetetraacetic acid (CuEDTA)] that result in early abscission of leaves, usually while the leaves are still green. Chemical-induced defoliation of deciduous trees decreases the amount of $\mathrm{N}$ mobilized from leaves to stems and roots in the autumn; thus, it can reduce $\mathrm{N}$ reserves required for growth the following spring (Bi et al., 2003; Guak et al., 2001). The combination of foliar sprays with urea and CuEDTA can be used to obtain efficient early defoliation and promote $\mathrm{N}$ storage without reducing plant growth performance the following year (Bi et al., 2005; Guak et al., 2001). Early defoliation before terminal buds set can also inhibit the development of dormancy and cold hardiness (Fuchigami, 1970). To survive in cold storage and grow well during the following growing season, trees must have enough reserve nutrients and develop dormancy.

Surface wounds inflicted during harvest and leaf scars caused by artificial or natural defoliation and subsequent handling can serve as infection openings for P. syringae, but the pathogen is unsuccessful in causing infection of uninjured bark (Bostock and Doster, 1985; De Bruyn, 1924; Linderman,

\begin{tabular}{llll}
\hline $\begin{array}{l}\text { Units } \\
\text { To convert U.S. to SI, } \\
\text { multiply by }\end{array}$ & U.S. unit & SI unit & $\begin{array}{l}\text { To convert SI to U.S., } \\
\text { multiply by }\end{array}$ \\
\hline 29.5735 & $\mathrm{fl} \mathrm{oz}$ & $\mathrm{mL}$ & 0.0338 \\
3.7854 & gal & $\mathrm{L}$ & 0.2642 \\
2.54 & inch(es) & $\mathrm{cm}$ & 0.3937 \\
25.4 & inch(es) & $\mathrm{mm}$ & 0.0394 \\
0.001 & $\mathrm{ppm}$ & $\mathrm{g} \cdot \mathrm{L}^{-1}$ & 1000 \\
0.001 & $\mathrm{ppm}$ & $\mathrm{mg} \cdot \mathrm{g}^{-1}$ & 1000 \\
1 & $\mathrm{ppm}$ & $\mathrm{mg} \cdot \mathrm{L}^{-1}$ & 1 \\
0.001 & $\mathrm{ppm}$ & $\mathrm{mL} \cdot \mathrm{L}^{-1}$ & 1000 \\
$\left({ }^{\circ} \mathrm{F}-32\right) \div 1.8$ & ${ }^{\circ} \mathrm{F}$ & ${ }^{\circ} \mathrm{C}$ & $\left(1.8 \times{ }^{\circ} \mathrm{C}\right)+32$
\end{tabular}


1986; Pscheidt and Ocamb, 2002). Recently, growers of pear nursery trees in the PNW have reported increased incidence and severity of damage to trees by $P$. syringae when 'Old Home $\times$ Farmington 97' pear ('OHF 97') rootstock is sprayed with urea and chemical defoliants. It was hypothesized that the combination of urea and defoliant treatment predisposes the trees to $P$. syringae infection by inflicting injury to the stem tissue or by indirectly making the trees more susceptible to infection by increasing tree $\mathrm{N}$ content. With other plant pathogens, abundant $\mathrm{N}$ can make trees more susceptible to pathogens and increase the length of time trees are more susceptible (Frecon, 1982; Simon et al., 2003).

Infection of bare-rooted nursery trees by $P$. syringae during cold storage could result from subjecting trees to environmental conditions that favor the growth of the pathogen and/ or are unfavorable to maintaining optimal physiological condition of the plant (Pscheidt and Ocamb, 2002). The combination of host predisposition and cold, wet conditions in cold storage or outdoors favorable for pathogen activity increases the potential for disease. In addition, P. syringae infection might be favored by the physiological or physical condition of the plant during harvesting and subsequent handling and storage. It is possible that trees harvested before they are dormant may be more susceptible to $P$. syringae and that surface wounds or leaf scars resulting from urea and defoliant sprays and harvesting and handling procedures could also serve as infection openings for $P$. syringae.

Increased damage by $P$. syringae has not been reported for the majority of plant species that are sprayed with urea and defoliants during production. Some nurserymen report that early defoliation of trees treated with the combination of urea and defoliant may actually reduce the incidence or severity of diseases (L. Lyon, personnel communication). Reduced disease incidence and severity in response to early defoliation may be a result of more complete healing of leaf scars before the cold, wet conditions in the autumn when the potential for P. syringae infection is high. Additionally, early defoliation enables trees to be harvested and stored before the onset of environmental conditions that promote the activity and subsequent infection by P. syringae (Bostock and Doster, 1985). The effect of urea and defoliants on disease incidence and severity caused by $P$. syringae appears to be species specific and may be related to the time autumn sprays are used during production.

Common control measures for $P$. syringae in nursery production include a combination of good nursery sanitation practices and chemical application. Phosphonate-containing fungicides, including fosetyl-aluminum (fosetyl-Al) and its breakdown product, phosphorous acid (also referred to as phosphonate) are commonly used to control Phytophthora species (Doster and Bostock, 1988; Erwin and Ribeiro, 1996). It is applied to trees as sprays, drenches, dips, or by injection (Erwin and Ribeiro, 1996; Pegg et al., 1987; Quimete and Coffey, 1989; Tidball and Linderman, 1990). Fosetyl-Al translocates upward and downward (in the transpiration stream and in the phloem sap) and may have direct fungal toxicity activity against Phytophthora species, or induces host plant resistance (Erwin and Ribeiro, 1996). Although chemical control measures exist for this pathogen, the influence of these chemicals on controlling the disease may be affected by the use of urea and defoliant sprays during nursery production.

Our specific objectives were to determine whether susceptibility of field-grown pear trees to $P$. syringae is related to $\mathrm{N}$ concentration in stems and is altered by spraying trees with urea or the defoliant CuEDTA at different times in the autumn before and after inoculation with the pathogen. Additionally, we also evaluated whether the effects of fungicides containing fosetyl-Al and phosphorous acid on $P$. syringae are altered by spraying trees with urea or CuEDTA.

\section{Materials and methods}

INOCULUM PRODUCTION AND WOUND INOCULATION. Stock cultures of $P$. syringae [isolated from mountain laurel (Kalmia latifolia) by $\mathrm{R}$. Linderman, USDA-ARS, Corvallis, $\mathrm{OR}$ ] were maintained on V8 juice agar (V8A) medium (Guo and Ko, $1993)$ in the dark at $20{ }^{\circ} \mathrm{C}$. Fresh cultures were prepared 7 to $10 \mathrm{~d}$ before inoculation by transferring 4-mm-diameter agar plugs to plates containing V8A medium and incubated in the dark at $20^{\circ} \mathrm{C}$. Wounds on stems were inoculated using mycelial plugs ( $4 \mathrm{~mm}$ diameter) taken from the actively growing margin of colonies of $P$. syringae growing on V8A medium. Plugs with or without the pathogen were placed into a wound made with a cork borer (4 $\mathrm{mm}$ diameter). Three wounds were made on the stem of each tree and two wounds were inoculated with plugs of $P$. syringae grown on V8A and one wound was inoculated with plugs of V8A.Wounds were wrapped with wax-coated plastic film (parafilm ${ }^{\circledR} \mathrm{M}$; Alcan, Montreal, QC, Canada) after inoculation.

EXPERIMENT 1. Nursery-grown pear 'OHF 97' rootstocks were planted into 1 -gal containers filled with a mixture of douglas fir bark, peatmoss, and pumice (1:1:1 by volume) on 26 Mar. 2002. The trees were grown in a lath house at Oregon State University (OSU), Corvallis (lat. $44^{\circ} 30^{\prime} \mathrm{N}$, long. $123^{\circ} 17^{\prime} \mathrm{W}$ ), trained to a single stem, and fertigated with $400 \mathrm{~mL}$ of a complete fertilizer containing $20 \mathrm{~N}-$ 8.8P-16.6K $\left(150 \mathrm{mg} \cdot \mathrm{L}^{-1}\right.$ Plantex ${ }^{\circledR}$ 20-20-20 with micronutrients; Plantex, Brampton, ON, Canada) once per week from 18 June to 30 July 2002.

In Aug. 2002, 144 trees were selected for uniformity based on stem diameter $(7-8 \mathrm{~mm})$ and divided into three groups of 48 trees. Trees in each group were fertigated twice per week ( $\mathrm{N}$ fertigation treatment) with $400 \mathrm{~mL}$ of modified Hoagland's solution number 2 (Hoagland and Arnon, 1950) containing 0, 100, or $200 \mathrm{mg} \cdot \mathrm{L}^{-1}$ total $\mathrm{N}$ from ammonium nitrate $\left(\mathrm{NH}_{4} \mathrm{NO}_{3}\right)$. Trees in each fertigation treatment were divided into four groups of 12 trees and leaves on trees in each group were sprayed until runoff (autumn spray treatments) with 1) water on 26 Oct. 2002 and 9 Nov. 2002, 2) urea $\left(30 \mathrm{~mL} \cdot \mathrm{L}^{-1}\right.$ urea, $46 \mathrm{~N}-0 \mathrm{P}-0 \mathrm{~K})$ on 26 Oct. 2002 and water on 9 Nov. 2002,3) water on 26 Oct. 2002 and CuEDTA $\left(10 \mathrm{~mL} \cdot \mathrm{L}^{-1}\right.$ Librel ${ }^{\circledR}$; Ciba, Suffolk, VA) on 9 Nov. 2002, or 4) urea on 26 Oct. 2002 and CuEDTA on 9 Nov. 2002. Stems on six trees in each $\mathrm{N}$ fertigation $\times$ autumn spray treatment combination were inoculated with the pathogen $7 \mathrm{~d}$ before sprays (19 Oct. 2002) or $7 \mathrm{~d}$ after sprays (16 Nov. 2002). Inoculum production and wound inoculation was performed as described above.

Disease severity (length of lesion in centimeters) was measured on trees 
after natural defoliation occurred on trees sprayed with water (21 Dec. 2002). Stems were removed from trees using pruning shears and were placed into a $-80{ }^{\circ} \mathrm{C}$ freezer, freezedried, then ground with a Wiley mill (20 mesh) and reground with a cyclone mill (60 mesh). The $\mathrm{N}$ concentration of ground samples was determined using the Kjeldahl method (Horneck et al., 1989). Concentrations of free amino acids were determined by the ninhydrin assay (Yemm and Cocking, 1955).

The experiment was a completely randomized design with three factors: $\mathrm{N}$ fertigation rate in August $(0,100$, and $200 \mathrm{mg} \cdot \mathrm{L}^{-1} \mathrm{~N}$ ), autumn spray treatment (water, urea, CuEDTA, and urea + CuEDTA), and inoculation time (before or after autumn spray treatments). Each treatment had six replications. No lesions occurred on wounds inoculated with only V8A; therefore, only lesion size data from wounds inoculated with the pathogen were included in the analyses. Data were analyzed using multivariate analysis of variance (MANOVA) in a complete factorial design to determine whether treatments influenced $\mathrm{N}$ and amino acid concentrations in stems, and lesion size on stems. MANOVA was used to control experiment-wide error rate before further univariate analysis. When the overall multivariate test was significant for a main effect or interaction, the univariate F-tests for each variable was examined to identify the specific dependent variables that contributed to the significant overall effect. Means for significant main effects or their highest order interactions from MANOVA are presented in figures and were separated using Tukey's honestly significant difference at $P<$ $0.05\left(\mathrm{THSD}_{0.05}\right)$. Polynomial contrasts were used to evaluate the influence of $\mathrm{N}$ fertigation rate on response variables. Relationships between lesion size and stem $\mathrm{N}$ and amino acid concentrations were assessed using Pearson's correlation coefficient (r). Binomial analyses (Wald Statistic, W) were used to determine treatment effects on disease incidence and data from significant $(P<0.05)$ factor interactions are presented in figures. All statistical analyses were performed with S-Plus (version 6.0; MathSoft, Seattle) and Statistica (version 8.0; Statsoft, Tulsa, OK).

Experiment 2. Pear 'OHF 97' rootstocks were planted into 1 -gal containers filled with a mixture of douglas-fir bark, peatmoss, and pumice (1:1:1, by volume) on 21 May 2003. The trees were grown in a lath house at OSU, trained to a single stem, and fertigated with a complete fertilizer with micronutrients (200 $\mathrm{mg} \cdot \mathrm{L}^{-1}$ Plantex ${ }^{\circledR}$ 20-20-20 with micronutrients) once per week from 6 June to 5 Sept. 2003.

In Oct. 2003, 80 trees were selected for uniformity based on stem diameter (7-8 $\mathrm{mm}$ ) and divided into two groups of 40 trees. Trees in each group were sprayed with a factorial combination of urea, defoliant, and fungicide treatments on 5 Oct. 2004 or 13 Nov. 2004. At each spray date, leaves on five trees were sprayed until runoff with one of a factorial combination of urea treatment (water or $30 \mathrm{~mL} \cdot \mathrm{L}^{-1}$ urea), defoliant treatment (water or $10 \mathrm{~mL} \cdot \mathrm{L}^{-1} \mathrm{CuEDTA}$ ), and fungicide treatment [water or a fungicide solution composed of fosetyl-Al and silica (6 g. $\mathrm{L}^{-1}$ Alliette $\AA$; Bayer Crop Science, Research Triangle Park, NC)]. Stems on five trees in each treatment combination were inoculated with $P$. syringae 1 week after spray treatments (12 Oct. 2003 and 20 Nov. 2003). Inoculum production, wound inoculation, and assessment of disease severity were performed as described above.

Length of lesions $(\mathrm{cm})$ was measured on trees 8 weeks after inoculation. Stems of trees inoculated on 12 Oct. 2003 and 20 Nov. 2003 were assessed on 7 Dec. 2003 and 15 Jan. 2004, respectively. After each assessment, stems were removed from trees using pruning shears, and $\mathrm{N}$ concentration of stems was determined as described above.

The experiment was a completely randomized design with four factors: Time of spray treatment (October or November), urea treatment (water or urea), defoliant treatment (water or CuEDTA), and fungicide treatment (water or fosetyl-Al). Each treatment had five replications. No lesions occurred on wounds inoculated with only V8A. All stems inoculated with the pathogen developed lesions except stems from treatments that included fosetyl-Al (data not shown). Only one stem from a tree sprayed with fosetyl-Al developed lesions; therefore, only lesion size data from stems not sprayed with fosetyl-Al were included in statistical analyses.
All data were tested for homogeneity of variance using Levene's test and for normality using the KolmogorovSmirnov test. Lesion size data from treatments not including fosetyl-Al could not be transformed to meet homogeneity of variance assumptions of analysis of variance (ANOVA); therefore, data were analyzed using Kruskal-Wallis ANOVA at $P<0.05$ $\left(\mathrm{K}-\mathrm{W}_{0.05}\right)$ by comparing specific treatment combinations. Lesion size data were assessed using $\mathrm{K}-\mathrm{W}_{0.05}$ across spray treatments (water, urea, CuEDTA, and urea + CuEDTA) and spray time (October and November) to compare spray treatment effects on lesion size at different spray times (spray treatment $\times$ spray time interaction). $\mathrm{N}$ concentration data from all stems were analyzed in a complete factorial design with spray time, urea treatment, and defoliant treatment as main effects using ANOVA to determine whether treatments influenced stem $\mathrm{N}$ concentration. Means for significant main effects or their highest order interactions from ANOVA are presented in figures and were separated using $\mathrm{THSD}_{0.05}$. The relationships between lesion size and stem $\mathrm{N}$ concentration were assessed using Spearman's rank correlation $(\mathrm{R})$.

Experiment 3. Pear 'OHF 97' rootstocks were planted into l-gal containers filled with a mixture of douglas-fir bark, peatmoss, and pumice (1:1:1 by volume) on 1 June 2004 . The trees were grown in a lath house at OSU, trained to a single stem, and fertigated with a complete fertilizer with micronutrients $\left[200 \mathrm{mg} \cdot \mathrm{L}^{-1}\right.$ Plantex® 20-20-20 with micronutrients] once per week from 14 June to 18 Aug. 2004.

In Oct. 2004, 128 trees were selected for uniformity based on diameter $(9 \mathrm{~mm})$ and divided into two groups of 64 trees. Trees in each group were sprayed with a factorial combination of urea and fungicide treatments on 22 Oct. 2004 or 24 Nov. 2004. At each spray date, leaves on 16 trees were sprayed until runoff with one of a factorial combination of urea treatment (water or $30 \mathrm{~mL} \cdot \mathrm{L}^{-1}$ urea and $10 \mathrm{~mL} \cdot \mathrm{L}^{-1}$ CuETDA), and fungicide treatment \{water or a fungicide solution composed of phosphorous acid $\left(\mathrm{H}_{3} \mathrm{PO}_{3}\right)$ neutralized with potassium hydroxide $(\mathrm{KOH})$ [PFOS (10 mL $\cdot \mathrm{L}^{-1}$ PhytoFos ${ }^{\circledR}$; Sipcam Agro USA, Research Triangle Park, NC)]\}. 
Stems on four trees in each treatment were inoculated with $P$. syringae 1 week before spray treatments $[-7 \mathrm{~d}$ (15 Oct. 2004 or 17 Nov. 2004)], or 2 d [ 2 d (24 Oct. 2004 or 26 Nov. 2004)], l week [7 d (29 Oct. 2004 or 1 Dec. 2005)], or 3 weeks [21 d (12 Nov. 2004 or 15 Dec. 2004)] after spray treatments). Inoculum production, wound inoculation, and assessment of disease severity were performed as described above. Additionally, three inoculations were also made on the same stem of each tree without artificially wounding the stem: two locations were inoculated with the pathogen grown on V8A and one location was inoculated with V8A.

The length of lesions was measured on trees 8 weeks after inoculation. Stems of trees inoculated at -7 , 2,7 , and $21 \mathrm{~d}$ in the October spray treatments were assessed on $10 \mathrm{Dec}$. 2004, 19 Dec. 2004, 24 Dec. 2004, and 7 Jan. 2005, respectively. Stems of trees inoculated at $-7,2,7$, and 21 $\mathrm{d}$ in the November spray treatment were assessed on 12 Jan. 2005, 21 Jan. 2005, 26 Jan. 2005, and 9 Feb. 2005 , respectively. All stems were harvested using pruning shears, and $\mathrm{N}$ concentration of stems was determined as described above.

The experiment was a completely randomized design with four factors: Time of spray application (October or November), urea treatment (water or urea + CuEDTA), fungicide treatment (water or PFOS), and time of inoculation $(-7,2,7$, or $21 \mathrm{~d})$. Each treatment had four replications. No lesions occurred on wounds inoculated with only V8A and no lesions occurred on stems inoculated without wounds; therefore, only lesion size data from wounds and stems inoculated with the pathogen were included in the analyses. All data were tested for homogeneity of variance using Levene's test and for normality using the Kolmogorov-Smirnov test. Lesion size data could not be transformed to meet homogeneity of variance assumptions of ANOVA; therefore, data were analyzed using Kruskal-Wallis ANOVA by comparing specific treatment combinations. Lesion size data were assessed using $\mathrm{K}-\mathrm{W}_{0.05}$ across spray treatment (water, urea, PFOS, and urea + PFOS) and spray times (October and November) to compare spray treatment effects on lesion size at different spray times (spray treatment $\times$ spray time interaction); across spray time and inoculation times $(-7,2,7$, and $21 \mathrm{~d})$ to determine whether timing of pathogen presence influenced lesion size at different spray times (inoculation time $\times$ spray time interaction); and across spray treatments and inoculation times to determine whether timing of pathogen presence influenced lesion size of trees spray with different treatments (spray treatment $\times$ inoculation time interaction). $\mathrm{N}$ concentration data from all stems were analyzed in a complete factorial design with spray time, urea treatment, fungicide treatment, and inoculation time as main effects using ANOVA to determine whether treatments influenced stem $\mathrm{N}$ concentration. Means for significant main effects or their highest order interactions from ANOVA are presented in figures and were separated using $\mathrm{THSD}_{0.05}$. The relationships between lesion size and stem $\mathrm{N}$ concentration were assessed using $\mathrm{R}$.

\section{Results}

EXPERIMENT 1. All stems inoculated with $P$. syringae $7 \mathrm{~d}$ after being sprayed developed lesions, and inoculating trees after spraying resulted in similar or higher disease incidence than inoculating trees before spraying (Fig. 1, A and E). Stems from trees inoculated after spraying had similar or lower $\mathrm{N}$ and amino acid concentrations and developed larger lesions than stems from trees inoculated before spraying (Fig. 1, B-D and $\mathrm{F}-\mathrm{H}$ ). There were positive correlations between lesion size and stem $\mathrm{N}(\mathrm{R}=$ $0.660 ; P<0.05)$ and amino acid $(\mathrm{R}=$ $0.503 ; P<0.05)$ concentrations when stems were inoculated before being sprayed and positive correlations between lesion size and stem $\mathrm{N}$ $(\mathrm{R}=0.597 ; P<0.05)$ and amino acid $(\mathrm{R}=0.494 ; P<0.05)$ concentrations after being sprayed.

Stems from trees sprayed with water or CuEDTA alone had similar disease incidence and lesion size and lower $\mathrm{N}$ and amino acid concentrations than stems from trees sprayed with urea or a combination of urea and CuEDTA (Fig. 1, E-H). There were positive correlations between lesion size and stem $\mathrm{N}(\mathrm{R}=0.578$; $P<0.05)$ and amino acid $(\mathrm{R}=0.505$; $P<0.05)$ concentrations when trees were sprayed with urea and positive correlations between lesion size and stem $\mathrm{N}(\mathrm{R}=0.543 ; P<0.05)$ and amino acid $(\mathrm{R}=0.507 ; P<0.05)$ when trees were sprayed with a combination of urea and CuEDTA. There were no correlations between lesion size and stem $\mathrm{N}$ and amino acid concentrations when trees were sprayed with water or CuEDTA alone $(\mathrm{R}<$ $0.163 ; P>0.05)$.

Increasing $\mathrm{N}$ rate in August increased stem $\mathrm{N}$ and amino acid concentrations and the size of lesions on stems from trees in all spray treatments (Fig. 1, J-L). On average, stems from trees grown with no $\mathrm{N}$ during August had similar or lower disease incidence, smaller lesions, and lower $\mathrm{N}$ and amino acid concentrations than stems from trees grown with 100 or $200 \mathrm{mg} \cdot \mathrm{g}^{-1} \mathrm{~N}$ during August (Fig. 1, A-D). The influence of August $\mathrm{N}$ rate on stem $\mathrm{N}$ concentrations was greater when trees were sprayed with urea or a combination of urea and CuEDTA than when trees were sprayed with water or CuEDTA alone (Fig. 1K). The influence of August N rate on lesion size and stem amino acid concentration was greater when trees were sprayed with urea, CuEDTA, or a combination of urea and CuEDTA than when trees were sprayed with water (Fig. I, J and L).

EXPERIMENT 2. Lesions developed on over $100 \%$ of wounds inoculated with the pathogen except on stems from treatments that included fosetyl-Al (data not shown). Stems from trees sprayed in October developed smaller lesions and had similar or higher $\mathrm{N}$ concentrations than stems from trees sprayed in November (Fig. 2, A and B). Stems from trees sprayed with water in October had lower $\mathrm{N}$ concentrations and developed larger lesions than stems from trees sprayed with urea or a combination of urea and CuEDTA. Stems from trees sprayed with water in November had similar $\mathrm{N}$ concentrations and developed smaller lesions than stems from trees in all other spray treatments. Stems from trees sprayed with CuEDTA in October had lower $\mathrm{N}$ concentrations and developed larger lesions than stems from trees sprayed with urea or a combination of urea and CuEDTA. Stems from trees sprayed with CuEDTA in November had lower stems $\mathrm{N}$ concentrations and developed smaller lesions than trees sprayed with a combination of urea and CuEDTA. Stems 

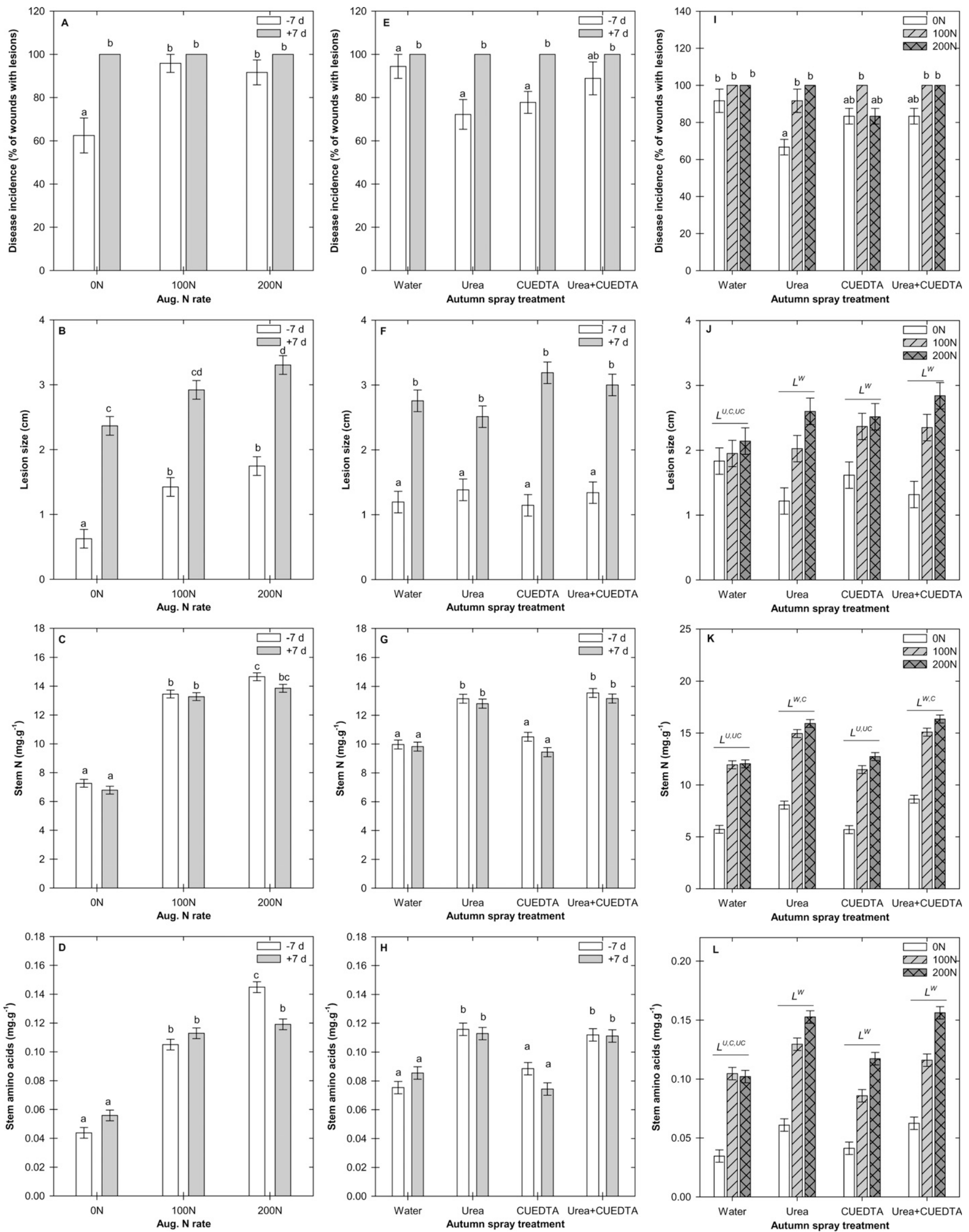

Fig. 1. Continued 
from trees sprayed with urea had similar $\mathrm{N}$ concentrations and developed similar lesions as trees sprayed with a combination of urea and CuEDTA, regardless of when trees were sprayed.

Lesion size was not correlated with stem $\mathrm{N}$ concentrations when trees were sprayed with water or CuEDTA in October $(\mathrm{R}<0.350 ; P>0.05)$. Lesions size was positively correlated $(P<0.05)$ with stem $\mathrm{N}$ concentrations when trees were sprayed with urea $(\mathrm{R}=$ $0.700 ; P<0.05)$ or a combination of urea and CuEDTA $(\mathrm{R}=0.573 ; P<$ $0.05)$ in October. Lesion size was positively correlated with stem $\mathrm{N}$ concentrations when trees were sprayed with water $(\mathrm{R}=0.632 ; P<0.05)$ or CuEDTA $(\mathrm{R}=0.574 ; P<0.05)$ in November, and lesion size was not correlated with stem $\mathrm{N}$ concentrations when trees were sprayed with urea or a combination of urea and CuEDTA in November $(\mathrm{R}<0.221 ; P>0.05)$.

EXPERIMENT 3. Lesions developed on over $75 \%$ of wounds (data not shown). Trees sprayed with the urea treatment (urea and CuEDTA) in October defoliated before trees that were sprayed with the urea treatment in November (data not shown).

Between October and November, stem $\mathrm{N}$ concentrations increased in trees from all spray treatments and lesion size increased between October and November when trees were sprayed with water or the urea treatment (Fig. 3, A and B). Stems from trees sprayed with water had lower $\mathrm{N}$ concentrations and developed similar size (October) or larger (November) lesions than stems from trees sprayed with the urea treatment (Fig. 3, A and B). Across all spray times and inoculation times, there were positive correlations between stem $\mathrm{N}$ concentration and lesion size when trees were sprayed with water $(\mathrm{R}=0.531$, $P<0.05)$ and the urea $(\mathrm{R}=0.465$; $P<0.05)$ treatment. Trees sprayed with PFOS or a combination of the urea treatment and PFOS developed the smallest lesions and had similar or higher stem $\mathrm{N}$ concentrations than trees sprayed with water or the urea treatment (Fig. 3, A and B). There were no significant correlations between stem $\mathrm{N}$ concentration and lesion size when trees were sprayed with PFOS or a combination of the urea treatment and PFOS $(\mathrm{R}<0.182$; $P>0.05)$.

Lesion size and stem $\mathrm{N}$ concentrations increased between October and November regardless of when trees were inoculated (Fig. 3, C and D). Stems from trees inoculated 7 and $21 \mathrm{~d}$ after spraying in October had higher $\mathrm{N}$ concentrations and developed similar size lesions than stems from trees inoculated $7 \mathrm{~d}$ before and $2 \mathrm{~d}$ after spraying (Fig. 3, C and D). Stems from trees inoculated $7 \mathrm{~d}$ before spraying in November had similar or lower stem $\mathrm{N}$ concentrations and developed larger lesions than trees inoculated after spraying (Fig. $3, \mathrm{C}$ and D). Stems from trees inoculated $2 \mathrm{~d}$ after spraying in November had lower stem $\mathrm{N}$ concentrations and developed similar size lesions as trees inoculated 7 and $21 \mathrm{~d}$ after spraying (Fig. 3, C and D). There were positive correlations between stem $\mathrm{N}$ concentration and lesion size when trees were inoculated before being sprayed with water $(\mathrm{R}=$ $0.708 ; P<0.05)$ and the urea treatment $(\mathrm{R}=0.747 ; P<0.05)$. There was no correlation between stem $\mathrm{N}$ concentration and lesion size then stems were inoculated after being sprayed with water and the urea treatment $(\mathrm{R}<0.235 ; P>0.05)$.

\section{Discussion}

STEM $\mathbf{N}$ CONCENTRATION AND SUSCEPTIBILITY. Our results indicate there are certain conditions that result in positive relationships between $\mathrm{N}$ concentrations in stems of pear trees and susceptibility to $P$. syringae. Positive correlations between stem $\mathrm{N}$ concentration and lesion size occurred for certain treatment combinations, time of year, and inoculation times in all three experiments. For example, in Expt. 1, increasing the $\mathrm{N}$ fertigation rate in August, increased stem $\mathrm{N}$ concentration, and increased size of lesions on stems; in Expt. 2 , trees sprayed with CuEDTA in November had lower stem $\mathrm{N}$ concentrations and smaller lesions than trees sprayed with a combination of urea and CuEDTA; in Expt. 3, trees sprayed in November had higher stem $\mathrm{N}$ concentrations and developed larger lesions than trees sprayed in October, and in Expt. 3, there were positive correlations between stem $\mathrm{N}$ concentration and lesion size when trees were inoculated before being sprayed with water or urea. Taken together, these results suggest that trees with higher $\mathrm{N}$ concentrations were more susceptible to $P$. syringae. There are several reports for high $\mathrm{N}$ fertilization rates increasing plant susceptibility to pathogen infection, including high rates of $\mathrm{N}$ fertilizer increasing disease severity caused by $P$. infestans on potato [Solanum tuberosum (Herlihy, 1970)], black shank caused by $P$. parasitica on tobacco [Nicotiana tabacum (Apple, 1962)], fire blight caused by Erwinia amylovora (Frecon, 1982), and Septoria tritici (Simon et al., 2003) and Fusarium head blight caused by $F$. graminearum and F. culmorum on

Fig. 1. Incidence of Phytophthora syringae infection (A, E, and I), nitrogen (B, F, and J) and amino acid (C, G, and K) concentrations in stems, and size of lesions ( $\mathrm{D}, \mathrm{H}$, and $\mathrm{L}$ ) on stems of 'OHF 97' pear rootstock grown with different nitrogen (N) rates during August (August $\mathrm{N}$ rate), sprayed with urea and chelated copper ethylenediaminetetraacetic acid (CuEDTA) in October and November, and inoculated with pathogen 19 Oct. 2002, $7 \mathrm{~d}$ before $(-7 \mathrm{~d})$ or $16 \mathrm{Nov} .2002,7 \mathrm{~d}$ after $(+7 \mathrm{~d})$ spray treatments. Stems were collected for analyses on 21 Dec. 2002 . August $\mathrm{N}$ rate $=$ trees fertigated with $400 \mathrm{~mL}(13.53 \mathrm{fl} \mathrm{oz}) \mathrm{of}$ $0(0 \mathrm{~N}), 100(100 \mathrm{~N})$, or $200(200 \mathrm{~N}) \mathrm{mg} \cdot \mathrm{L}^{-1}(\mathrm{ppm}) \mathrm{N}$ during Aug. 2002; Autumn spray treatment = trees sprayed with water (Water), urea solution (Urea), CuEDTA solution (CUEDTA), or a combination of urea and CuEDTA (Urea + CUEDTA) on 26 Oct. and 9 Nov. 2002. (A, E, and I); Disease incidence = percentage of stems with lesions. Columns denoted with the same lower case letters are not significantly different at $P>0.05$ as indicated by binomial analyses and multivariate analysis of variance (lesion size and stem concentration.). (B, C, F, G, D, and H) Columns denoted with the same lower case letter are not significantly different using Tukey's honestly significant difference at $P<0.05$. (J-L) Significant $(P<0.05)$ linear $(L)$ contrasts based on August $\mathrm{N}$ rate within an autumn spray treatment denoted by $L$ above column groups. Significant $(P<0.05)$ differences in $L$ response to August $N$ rate between autumn spray treatments denoted in superscripts. Columns represent means and error bars are se (A-D: $\mathrm{n}=24 ; \mathrm{E}-\mathrm{H}: \mathrm{n}=18 ; \mathrm{I}-\mathrm{L}: \mathrm{n}=12) ; 1 \mathrm{~cm}=0.3937 \mathrm{inch}, 1 \mathrm{mg} \cdot \mathrm{g}^{-1}=1000 \mathrm{ppm}$. 

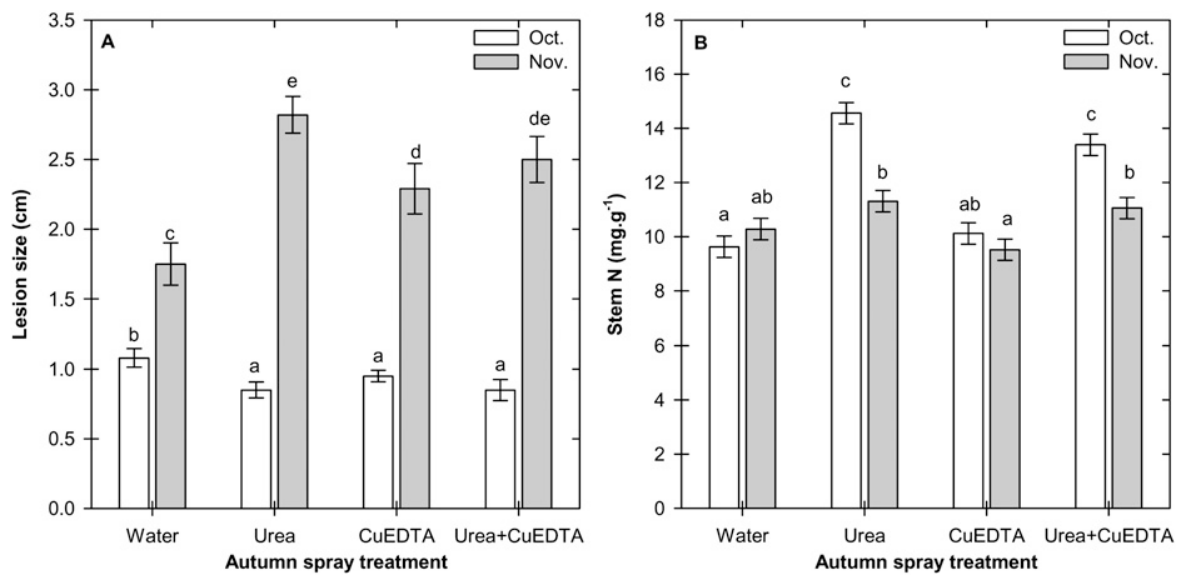

Fig. 2. Nitrogen (N) concentrations in stems (A) and the size of lesions (B) caused by Phytophthora syringae infection on stems of 'OHF 97' pear rootstock sprayed with urea and chelated copper ethylenediaminetetraacetic acid (CuEDTA) in October or November. Trees sprayed with water (Water), urea solution (Urea), CuEDTA, or a combination of urea and CuEDTA (Urea + CuEDTA) on 5 Oct. (Oct.) or 13 Nov. 2003 (Nov.) and inoculated with the pathogen $7 \mathrm{~d}$ after spraying. Stems were collected for analyses 8 weeks after inoculation. Columns represent means and error bars are se $(\mathbf{n}=\mathbf{5})$. Columns denoted with the same lower case letters are not significantly different (lesion size: Kruskal-Wallis test at $P<0.05$; stem $\mathrm{N}$ : Tukey's honestly significant difference test at $P<0.05) ; 1 \mathrm{~cm}=0.3937 \mathrm{inch}, 1 \mathrm{mg} \cdot \mathrm{g}^{-1}=1000 \mathrm{ppm}$.

wheat [Triticum aestivum (Lemmens et al., 2004)].

Our results suggest that the $\mathrm{N}$ status of pear trees is related to susceptibility to P. syringae; however, we did not always find positive relationships between $\mathrm{N}$ status and susceptibility. There were certain conditions that resulted in negative or no relationship between $\mathrm{N}$ concentrations in stems of pear trees and susceptibility to P. syringae. For example, in Expt. 1, stems inoculated after autumn spray treatments developed larger lesions than stems inoculated before spray treatments even though stem $\mathrm{N}$ and amino acid concentrations remained the same; in Expt. 1, spraying trees with CuEDTA decreased stem N concentrations and had no influence on lesion development; in Expt. 2, trees sprayed in November developed similar or lower stem $\mathrm{N}$ concentrations and developed larger lesions than trees sprayed in October; and in Expt. 3 , stems from trees sprayed with water had lower $\mathrm{N}$ concentrations and developed similar or larger lesions than stems from trees sprayed with a combination or urea and CuEDTA. These results indicate that the relationship between $\mathrm{N}$ status and susceptibility is influenced by other changes in tree physiology during the autumn when exposed to the pathogen and is not strictly a function of $\mathrm{N}$ status.
There are several examples in our three experiments that indicate that the relationship between tree $\mathrm{N}$ status and susceptibility is confounded by the response of trees to different cultural practices (e.g., soil $\mathrm{N}$ application rate, sprays with urea, defoliant, or fungicide, and timing of sprays). In Expt. 1, increasing $\mathrm{N}$ fertigation rate in August increased stem N concentrations and lesion size, but spraying trees with urea in the autumn increased stem $\mathrm{N}$ concentrations and had no influence on lesion size. These results suggest that susceptibility of pear trees to P. syringae increases with increasing stem $\mathrm{N}$ concentrations but not when higher $\mathrm{N}$ concentrations are a result of urea sprays. In Expt. 2, spraying trees with CuEDTA lowered stem $\mathrm{N}$ concentrations, but lower $\mathrm{N}$ concentrations were associated with larger lesions when trees were sprayed in October and with smaller lesions when trees were sprayed in November. These results suggest that decreased stem $\mathrm{N}$ concentrations resulting from CuEDTA sprays are not directly related to susceptibility to P. syringae. Additionally, in Expt. $\mathrm{l}$, when trees were grown with no $\mathrm{N}$ during August, spraying trees with urea before inoculation increased stem $\mathrm{N}$ concentrations and decreased the size of lesions compared with trees sprayed with water. This result from trees grown with no $\mathrm{N}$ in $\mathrm{Au}-$ gust supports anecdotal reports from some growers who believe that spraying trees with urea in the autumn decreases disease severity caused by $P$. syringae in the nursery.

There are several examples in our three experiments that indicate that the relationship between tree $\mathrm{N}$ status and susceptibility is confounded by the time of year when trees are exposed to the pathogen and the potential effects of time of year on tree physiology and pathogen activity. For example, our results from all experiments indicate that trees were more susceptible to the pathogen in $\mathrm{No}^{-}$ vember when stem $\mathrm{N}$ concentrations were similar (Expt. 1), lower (Expt. 2 ), or higher (Expt. 3) than in October. Additionally, when stems were inoculated before being sprayed in November (Expt. 3), trees were more susceptible and had lower stem $\mathrm{N}$ concentrations than when trees were inoculated after being sprayed in November. Taken together, our results indicate that interactions between environmental conditions (e.g., temperature) and physiology of trees when inoculated with the pathogen (e.g., dormancy status) change the relationship between $\mathrm{N}$ status and tree susceptibility to the pathogen.

All of our experiments were done under natural environmental conditions, and differences in climate and physiology of trees between years may have caused differences in susceptibility associated with tree $\mathrm{N}$ concentration. Even though spraying trees with urea increased stem $\mathrm{N}$ concentrations in all years, lesions on trees that received urea sprays were larger, similar, or smaller than those on trees sprayed with water. This supports our theory that $\mathrm{N}$ content may be correlated with tree susceptibility, but other factors alter plant susceptibility to $P$. syringae. Additionally, in all of our experiments, lesions that developed from pathogen inoculation in October were smaller compared with lesions that developed from inoculation in November. This suggests that the level of pathogen activity or host susceptibility may relate to temperature.

In all of our experiments, trees inoculated with $P$. syringae on nonwounded stems showed no symptoms of disease and all wounds inoculated with the pathogen showed signs of disease. These results suggest that 

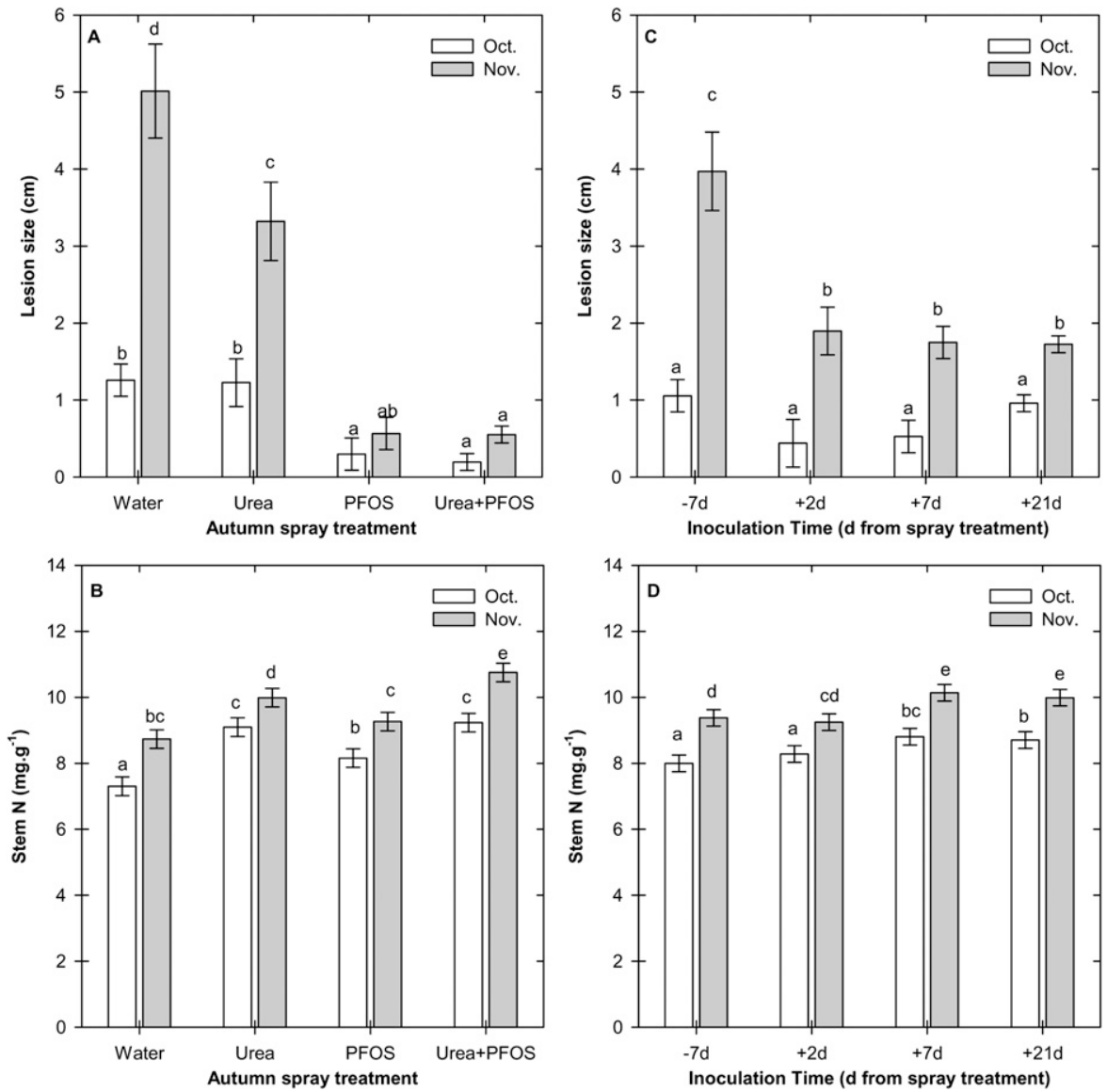

Fig. 3. Nitrogen concentration in stems (A) and the size of lesions (B) caused by Phytophthora syringae infection on stems of ' $\mathrm{OHF}$ 97' pear rootstock sprayed with urea, chelated copper ethylenediaminetetraacetic acid (CuEDTA), and a fungicide solution composed of phosphorus acid neutralized with potassium hydroxide [PFOS (PhytoFOS; Sipcam Agro USA, Research Triangle Park, NC)] in October or November. Trees sprayed with water (Water), a solution of urea and CuEDTA (Urea), a solution of PFOS (PFOS), or a solution of urea and PFOS (Urea + PFOS) on 22 Oct. (Oct.) or 24 Nov. 2004 (Nov.) and inoculated with pathogen $7 \mathrm{~d}$ before spraying $(-7 \mathrm{~d})$, or 2,7 , or $21 \mathrm{~d}(+2 \mathrm{~d},+7 \mathrm{~d}$, or $+21 \mathrm{~d})$ after spraying. Stems were collected for analyses 8 weeks after inoculation. Columns represent means and error bars are se $(n=16)$. Columns denoted with the same lower case letters are not significantly different (lesion size: Kruskal-Wallis test at $P<0.05$; stem N: Tukey's honestly significant difference test at $P<0.05) ; 1 \mathrm{~cm}=0.3937 \mathrm{inch,} 1 \mathrm{mg} \cdot \mathrm{g}^{-1}=$ 1000 ppm.

wounding may be essential for $P$. syringae infection of pear stems under the environmental conditions in our test system. Others have reported that $P$. syringae was unsuccessful in causing infection to uninjured bark of almond [Prunus dulcis (Bostock and Doster, 1985; De Bruyn, 1924; Linderman, 1986)], and P. syringae can infect wounds caused by handling or pruning or through leaves and leaf scars (De Bruyn, 1924; Linderman, 1986). In artificial inoculations of $P$. syringae in rhododendron (Rhododendron spp.), wounds and low temperatures were a prerequisite for infection (Linderman, 1986).
The activity of $P$. syringae is restricted to cold climates, and increased activity of the pathogen coincides with the dormancy period of deciduous trees (Duniway, 1983; Erwin and Ribeiro, 1996). Apple [Malus xdomestica (Sewell and Wilson, 1973)] and lilac [Syringa vulgaris (De Bruyn, 1924)] were more susceptible to $P$. syringae infection during the dormant period than in the actively growing period. The pathogen activity in apple (Sewell and Wilson, 1973) and almond (Bostock and Doster, 1985) was higher in cooler months at lower temperatures. This was also reported for the activity of this pathogen in orchard soil in southeastern England where the pathogen was quiescent during warmer months and active in cooler months (Harris, 1979). In bareroot nurseries, lifting of trees in the PNW coincides with the greatest activity of $P$. syringae. If infection occurs during this time and conditions that are conducive for pathogen activity follow, the risk of infection could be high, especially during cold storage, because the fungus can actively grow at low temperatures (Pscheidt and Ocamb, 2002).

UREA SPRAYS AND SUSCEPTIBILITY. In Expt. 2, spraying trees with urea in October increased $\mathrm{N}$ concentration and decreased tree susceptibility to $P$. syringae, while spraying trees with urea in November increased $\mathrm{N}$ concentrations and lesion size. This contrasting relationship between $\mathrm{N}$ concentration and the size of lesions between October and November suggests that time of year plays an important role in tree susceptible to $P$. syringae beyond the effects of urea on $\mathrm{N}$ status.

The results from Expt. 3 support our hypothesis that the relationship between stem $\mathrm{N}$ concentration and susceptibility varies during the autumn. Concentrations of $\mathrm{N}$ in stems from trees sprayed with urea in November were greater than in stems from trees sprayed in October, and lesions on stems from trees sprayed with urea were larger in November than in October. Compared with trees sprayed with water, spraying trees with urea in October had no influence on lesion size and increased stem $\mathrm{N}$ concentration, and spraying trees with urea in November decreased lesions size and increased stem $\mathrm{N}$ concentration. These results are important because they indicate that the timing of urea sprays can differentially influence tree $\mathrm{N}$ concentrations without altering susceptibility to $P$. syringae. Similarly, spraying pear trees with a combination of urea and CuEDTA had no influence on lesion size regardless of the growing environment before or after inoculation (Laywisadkul, 2008). These results suggest that the combined effects of urea and CuEDTA on stem $\mathrm{N}$ concentrations do not increase susceptibility of pear trees to $P$. syringae.

In general, our results indicate that spraying trees with urea has no effect on disease incidence and is 
not consistently associated with observed increases or decreases in susceptibility to $P$. syringae, even though urea sprays increase the concentrations of $\mathrm{N}$ and amino acids in stems. The relationship between tree susceptibility to $P$. syringae and tree $\mathrm{N}$ concentration may be specific to the form of $\mathrm{N}$ (e.g., urea vs. ammonium nitrate) and the delivery method or timing of $\mathrm{N}$ applications, not on the tree $\mathrm{N}$ status per se. Increasing $\mathrm{N}$ supply from fertigation and spraying trees with urea caused similar increases in stem $\mathrm{N}$ concentration in bench-grafted 'Fuji' apple on 'Malling 26' ('M26') rootstock (Cheng and Fuchigami, 2002) and June-budded 'Nonpareil' on 'Nemaguard' almond rootstocks (Bi et al., 2003). It is not known whether similar increases in stem $\mathrm{N}$ concentration resulting from spraying apple and almond trees with urea could increase tree susceptibility to pathogens.

CUEDTA SPRAYS AND SUSCEPTIBILITY. Our results suggest spraying trees with CuEDTA may increase the size of lesions caused by P. syringe, but the effects of CuEDTA on lesion size were not related to tree $\mathrm{N}$ concentrations. Lesions on stems inoculated before trees were sprayed with CuEDTA in Expt. 1 were smaller than lesions on stems inoculated after trees were sprayed; however, stems inoculated with $P$. syringae after trees were sprayed had similar $\mathrm{N}$ and amino acid concentrations as stems inoculated before trees were sprayed. This variable effect of CuEDTA on disease severity by $P$. syringae suggests that other factors, such as environment (e.g., temperatures) or stage of plant development (e.g., dormancy development), may be involved in the relationship between CuEDTA and susceptibility.

Spraying apple trees with CuEDTA can cause $>80 \%$ defoliation within $6 \mathrm{~d}$ of application and results in low $\mathrm{N}$ recovery from leaves compared with natural defoliation (Guak et al., 2001). Spraying almond and apple trees with CuEDTA in October has been shown to decrease stem $\mathrm{N}$ concentrations (Bi et al., 2005; Guak et al., 2001). Similar effects of CuEDTA on defoliation and loss of $\mathrm{N}$ have been reported for almond nursery trees $(\mathrm{Bi}$ et al., 2005). The effects of CuEDTA in our studies were not always consistent with reported effects of CuEDTA on defoliation; CuEDTA did not always cause premature defoliation before natural $\mathrm{N}$ translocation from leaves into tree stems. The poor efficiency of CuEDTA as a defoliant was supported by its lack of consistent influence on stem $\mathrm{N}$ concentrations in our experiments. Effects of CuEDTA on tree susceptibility to $P$. syringae in our experiments could not be directly related with stem $\mathrm{N}$ concentrations.

In our experiments, defoliation after spraying container-grown pear trees with CuEDTA took longer than defoliation in the experiments described above with apple and almond. With container-grown pear trees, it is possible that this longer time for defoliation resulted in mobilization of $\mathrm{N}$ back to stems and the other parts of the trees. Also, because only $\mathrm{N}$ concentrations in pear stems were analyzed, it is possible that $\mathrm{N}$ concentrations in roots were significantly decreased by spraying trees with CuEDTA, similar to the results described by Guak et al. (2001). In Expt. 2 , spraying pear trees with CuEDTA in October did not decrease stem N concentrations, but spraying trees with CuEDTA in November decreased $\mathrm{N}$ concentrations. The differences in concentration and timing of application between our studies and those from other studies may account for the different responses in $\mathrm{N}$ concentration to CuEDTA.

COMBINED UREA AND CUEDTA SPRAYS AND SUSCEPTIBILITY. Our results suggest that timing of spray treatments with urea and CuEDTA differentially influenced tree susceptibility to $P$. syringae, and the response depends on when trees were inoculated with the pathogen. In Expt. 3, when trees were sprayed in October, time of inoculation (e.g., before or after trees were sprayed) had no influence on lesion size. When trees were sprayed in November, stem lesions were largest when trees were inoculated before being sprayed. This suggests that sprays may physically or chemically alter tree susceptibility before pathogen presence, resulting in less disease. This result supports anecdotal reports from growers who believe using a combined spray of urea and CuEDTA decreases incidence of $P$. syringae in the nursery.

In our experiments, trees sprayed with a combination of urea and CuEDTA in November had similar stem $\mathrm{N}$ concentrations as trees sprayed with only urea and greater stem $\mathrm{N}$ concentrations than trees sprayed with only CuEDTA. Similar ameliorating effects of urea on $\mathrm{N}$ status of trees sprayed with CuEDTA have been reported by others (Bi et al., 2005; Guak et al., 2001). In our study, this effect was only observed when trees were sprayed in November and not October. Using similar concentrations of urea and CuEDTA, apple trees were sprayed two times with urea followed by one spray with CuEDTA in the work of Guak et al. (2001), and almond trees were sprayed with urea followed by a combined spray treatment of urea and CuEDTA by Bi et al. (2005). We used a single foliar application of urea + CuEDTA in our study, which may account for the lack of response in stem $\mathrm{N}$ concentration to the combined urea + CuEDTA spray. Splitting two urea applications, as described for almond (Bi et al., 2005), with a pretreatment of urea followed by the combination of urea and CuEDTA is a more useful strategy for improving $\mathrm{N}$ content in October compared with a single spray with a combination of urea and CuEDTA.

Our results from Expt. 3 support our hypothesis that the effects of urea and CuEDTA on susceptibility to $P$. syringae may be a function of the interaction between environment and plant development. The $\mathrm{N}$ concentrations in pear stems increased from October to the end of the experiment. Trees sprayed with a combination of urea and CuEDTA in October defoliated before trees that were sprayed with a combination of urea and CuEDTA in November. Increasing $\mathrm{N}$ concentrations during the autumn is a result of trees moving $\mathrm{N}$ from leaves to storage locations in the stems and roots before leaf abscission occurs (Bi et al., 2003; Cheng and Fuchigami, 2002). Compared with trees sprayed with water, trees sprayed with a combination of urea and CuEDTA in October and November had higher $\mathrm{N}$ concentrations in stems; however, the effects of urea on $\mathrm{N}$ concentrations in stems was less when trees were sprayed in November than in October. Between the October and November spray treatments, there may have been $\mathrm{N}$ mobilization from leaves to stems, resulting in higher $\mathrm{N}$ concentrations in stems of trees sprayed with water. The increase in $\mathrm{N}$ 
concentrations as trees sprayed with water became more dormant coincided with increased susceptibility to $P$. syringae. This supports our previous results showing that susceptibility of pear trees to $P$. syringae increases as trees become more dormant in the autumn and early winter (Laywisadkul, 2008).

Our results indicate that the timing of inoculation in relation to the timing of urea and CuEDTA sprays plays a role in disease severity and is independent of the effects of urea and CuEDTA on tree $\mathrm{N}$ concentrations. Therefore, differences in tree susceptibility to $P$. syringae before and after spray treatments were not related to concentrations of $\mathrm{N}$ and amino acids in stems. Susceptibility of pear trees to $P$. syringae increases as trees become more dormant in the autumn and early winter (Laywisadkul, 2008). It is possible that differences in lesion development between the two inoculation times were the result of environmental differences between the two inoculation times and influence on tree dormancy and disease severity.

CHEMICAL CONTROL AND SUSCEPTIBILITY. Fungicides used in our experiments effectively controlled activity of $P$. syringae when applied 7 and 2 d before inoculation. Fungicides containing fosetyl-Al (Expt. 2) and phosphorous acid (Expt. 3) decreased disease incidence and severity of $P$. syringae infection on pear stems in our experiments with little (Expt. 3 ) or no (Expt. 2) influence on stem $\mathrm{N}$ concentrations.

In Expt. 2, spraying trees with a fosetyl-Al-containing fungicides decreased disease severity without altering $\mathrm{N}$ concentrations in stems or defoliation. Others have also reported fosetyl-Al has good activity against $P$. cactorum (Bielenin and Jones, 1988; Ellis et al., 1998; Orlikowski et al., 1986; Thomidis and Elena, 2001), P. cinnamomi (Coffey et al., 1984; Darvas et al., 1984; Matheron and Mircetich, 1985; Pegg et al., 1987), P. citrophthora (Farih et al., 1981; Matheron and Mircetich, 1985), and $P$. syringae (Doster and Bostock, 1988). Our results indicate that using fosetyl-Al-containing fungicides in combination with urea or CuEDTA sprays is a compatible strategy for reducing disease caused by $P$. syringae without impacting growers' objective of increasing tree $\mathrm{N}$ concentrations with urea sprays or enhancing early defoliation with CuEDTA.

In Expt. 3, trees sprayed with a phosphorous acid-containing fungicide in October had higher stem N concentrations than trees sprayed with water. It is possible the October application of fungicide in Expt. 3 may have had a growth-stimulating influence on trees, resulting in increased $\mathrm{N}$ concentrations in stems. Phosphite has been reported as a nutritional and fungicidal material (Guest and Grant, 1991; Rickard, 2000; Varadarajan et al., 2002). Phosphite is not used as a substrate for phosphate-dependant enzymes because it is not converted to phosphate in trees (Carswell et al., 1996). However, it is not known how phosphite may alter $\mathrm{N}$ concentration when applied with urea + CuEDTA. Phosphite application to citrus (Citrus spp.) can cause similar increases in growth and fruit set similar to foliar sprays of urea (Lovatt, 1999). It is possible that the October application of fungicide in Expt. 3 may have had a phytotoxic effect on pear trees, causing premature leaf senescence and early mobilization of $\mathrm{N}$ from leaves back into stems. Although phosphite has been described as having low toxicity to plants (Guest and Grant, 1991), there are a number of reports of the development of phytotoxicity symptoms after foliar application of phosphite, including leaf burn (Walker, 1989; Wicks and Hall, 1988).

There are numerous reports of phosphorous acid as an effective control against $P$. cambivora in cherry [Prunus avium (Wicks and Hall, 1988)], P. cinnamomi on pineapple [Ananas comosus (Rohrback and Schenck, 1985)], eucalyptus [Eucalyptus spp. (Pilbeam et al., 2000; Wilkinson et al., 2001)], and avocado [Persea americana (Pegg et al., 1987)], $P$. citrophthora in citrus (Afek and Sztejnberg, 1989), and $P$. palmivora in cacao [Theobroma cacao (Holderness, 1990)]. Our results indicate that using phosphorous acid in combination with urea or CuEDTA sprays is a compatible strategy for reducing disease caused by $P$. syringae and the timing of phosphorous acid sprays in relation to urea or CuEDTA sprays will not influence its effects on disease control.

Conclusions. Spraying pear 'OHF 97' rootstock in the autumn with urea, defoliants, or fungicides containing fosetyl-Al or phosphite may influence tree $\mathrm{N}$ concentration, but their effects on $\mathrm{N}$ concentration are not directly related to susceptibility to $P$. syringae. Spraying pear trees with a combination of urea and CuEDTA after terminal buds have set in early autumn (October in PNW) can benefit nurserymen because the pathogen is less active in warm dry environments and the trees are better able to heal wounds caused by defoliation or chemical treatments. Trees sprayed in October have lower $\mathrm{N}$ reserves compared with trees sprayed in November or naturally defoliated trees; therefore, spraying trees in October will not have as much of a positive influence on tree growth the following year. Additionally, spraying trees with a combination of urea and CuEDTA with phosphonate-containing fungicides in early autumn can be of benefit for early harvesting and preventing the contamination and/or infection of $P$. syringae in the field or storage.

\section{Literature cited}

Afek, U. and A. Sztejnberg. 1989. Effect of fosetyl-Al and phosphorous acid on scoporone, a phytoalexin associated with resistance of citrus to Phytophthora citrophthora. Phytopathology 79:736739.

Apple, J.L. 1962. The development of black shank in tobacco as influenced by host nutrition. Phytopathology 51:386389.

Bi, G., C.F. Scagel, L. Cheng, and L.H. Fuchigami. 2005. Effects of copper, zinc, and urea on defoliation and nitrogen reserves in nursery plants of almond. J. Hort. Sci. Biotechnol. 80:746-750.

Bi, G., C.F. Scagel, L. Cheng, S. Dong, and L.H. Fuchigami. 2003. Spring growth of almond nursery trees depends upon nitrogen from both plant reserves and spring fertilizer application. J. Hort. Sci. Biotechnol. 78:853-858.

Bielenin, A. and A.L. Jones. 1988. Efficacy of sprays of fosetyl-Al and drenches of metalaxyl for the control of Phytophthora root and crown rot of cherry. Plant Dis. 72:477-480.

Bostock, R.M. and M.A. Doster. 1985. Association of Phytophthora syringae with pruning wound cankers of almond trees. Plant Dis. 69:568-571.

Carswell, C., B.R. Grant, M.E. Theodorou, J. Harris, J.O. Niere, and W.C. Plaxton. 
1996. The fungicide phosphite phosphonate starvation response in Brassica nigra seedlings. Plant Physiol. 110:105-110.

Cheng, L. and L.H. Fuchigami. 2002. Growth of young apple trees in relation to reserve nitrogen and carbohydrates. Tree Physiol. 22:1297-1303.

Coffey, M.D., H.D. Ohr, S.D. Campbell, and F.B. Guillemet. 1984. Chemical control of Phytophthora cinnamomi on avocado rootstocks. Plant Dis. 68:956-958.

Darvas, J.M., J.C. Toerien, and D.L. Milne. 1984. Control of avocado root rot by trunk injection with phosetyl-Al. Plant Dis. 68:691-693.

De Bruyn, H.L. 1924. The Phytophthora disease of lilac. Phytopathology 14:503517.

Doster, M.A. and R.M. Bostock. 1988. Chemical protection of almond pruning wounds from infection by Phytophthora syringae. Plant Dis. 72:492-494.

Duniway, J.M. 1983. Role of physical factors in the development of Phytophthora diseases, p. 175-187. In: D.C. Erwin, S. Bartnicki-Garcia, and P.H. Tsao (eds.). Phytophthora: Its biology, taxonomy, ecology, and pathology. APS Press, St. Paul, MN.

Ellis, M., W. Wilcox, and L. Madden. 1998. Efficacy of metalaxyl, fosetylaluminum, and straw mulch for control of strawberry leather rot caused by Phytophthora cactorum. Plant Dis. 82:329332.

Erwin, D.C. and O.K. Ribeiro. 1996. Phytophthora diseases worldwide. APS Press, St. Paul, MN.

Farih, A., J.A. Menge, P.H. Tsao, and H.D. Ohr. 1981. Metalaxyl and efosite aluminum for control of phytophthora gummosis and root rot on citrus. Plant Dis. 65:654-657.

Frecon, J.L. 1982. Commercial production of pear trees, p. 215-238. In: T. van der Zwet and N.F. Childers (eds.). The pear. Horticultural Publications, Gainesville, FL.

Fuchigami, L.H. 1970. Early defoliation may harm plants. Oregon Ornamental Nursery Dig. 14:3.

Guak, S., L. Cheng, and L.H. Fuchigami. 2001. Foliar urea pretreatment tempers inefficient $\mathrm{N}$ recovery resulting from copper chelate (CuEDTA) defoliation of apple nursery plants. J. Hort. Sci. Biotechnol. 76:35-39.

Guest, D. and B.R. Grant. 1991. The complex action of phosphonates as antifungal agents. Biol. Rev. Camb. Philos. Soc. 66:159-187.
Guo, L.Y. and W.H. Ko. 1993. Two widely accessible media for growth and reproduction of Phytophthora and Pythium species. Appl. Environ. Microbiol. 59:2323-2325.

Harris, D.C. 1979. The suppression of Phytophthora syringae in orchard soil by furalaxyl as a means of controlling fruit rot of apple and pear. Ann. Appl. Biol. 91:331-336.

Herlihy, M. 1970. Contrasting effects of nitrogen and phosphorous on potato tuber blight. Plant Pathol. 19:65-68.

Hoagland, D.R. and D.I. Arnon. 1950. The water-culture method for growing plants without soil. Californ. Agr. Expt. Sta. Circ. 347.

Holderness, M. 1990. Efficacy of neutralised phosphonic acid (phosphorous acid) against Phytophthora palmivora pod rot and canker of cocoa. Austral. Plant Pathol. 19:130-131.

Horneck, D.A., J.M. Hart, K. Topper, and B. Koepsel. 1989. Methods of soil analysis used in the soil testing laboratory at Oregon State University. Agr. Expt. Sta., Oregon State Univ., Corvallis, OR.

Laywisadkul, S. 2008. Factors affecting the incidence and severity of Phytophthora syringae cankers in pear (Pyrus communis) trees. PhD Thesis, Oregon State Univ., Corvallis, OR.

Lemmens, M., K. Haim, H. Lew, and P. Ruckenbauer. 2004. The effect of nitrogen fertilization on fusarium head blight development and deoxynivalenol contamination in wheat. J. Phytopathol. $152: 1-8$

Linderman, R.G. 1986. Phytophthora syringae blight, p. 15-17. In: D.L. Coyier and M.K. Rhone (eds.). Compendium of rhododendron and azalea diseases. APS Press, St. Paul, MN.

Lovatt, C.J. 1999. Timing citrus and avocado foliar nutrient applications to increase fruit set and size. HortTechnology 9:607-612.

Matheron, M.E. and S.M. Mircetich. 1985. Control of Phytophthora root and crown rot and trunk canker in walnut with metalaxyl and fosetyl Al. Plant Dis. 69:1042-1043.

Orlikowski, L.B., M. Leoni-Ebeling, and A. Schmidle. 1986. Efficacy of metalaxyl and phosethyl-aluminium in control of Phytophthora cactorum on apple trees. Z. Pflanzenkr. Pflanzenschutz 93:202-209.

Pegg, K.G., A.W. Whiley, P.W. Langdon, and J.B. Saranah. 1987. Comparison of phosetyl-Al, phosphorous acid and metalaxyl for the long-term control of Phytoph- thora root rot of avocado. Aust. J. Exp. Agr. 27:471-474.

Pilbeam, R., I. Colquhoun, B. Shearer, and G.S.J. Hardy. 2000. Phosphite concentration: Its effect on phytotoxicity symptoms and colonisation by Phytophthora cinnamomi in three understory species of Eucalyptus marginata forest. Austral. Plant Pathol. 29:86-95.

Pscheidt, J.W. and C.M. Ocamb. 2002. Pacific northwest plant disease management handbook. Agr. Expt. Sta., Oregon State Univ., Corvallis, OR

Quimete, D.G. and M.D. Coffey. 1989. Phosphonate levels in avocado (Persea americana) seedlings and soil following treatment with fosetyl-Al or potassium phosphite. Plant Dis. 73:212-215.

Rickard, D.A. 2000. Review of phosphorous acid and its salts as fertilizer materials. J. Plant Nutr. 23:161-180.

Ristaino, J.B. and M.L. Gumpertz. 2000. New frontiers in the study of dispersal and spatial analysis of epidemics caused by species in the genus Phytophthora. Annu. Rev. Phytopathol. 38:541-576.

Rohrbach, K.G. and S. Schenck. 1985. Control of pineapple heart rot caused by Phytophthora parasitica and P. cinnamomi with metalaxyl, fosetyl-Al and phosphorous acid. Plant Dis. 69:320-323.

Sewell, G.W.F. and J.F. Wilson. 1973. Phytophthora collar rot of apple: Seasonal effects on infection and disease development. Ann. Appl. Biol. 74:149-158.

Simon, M.R., C.A. Cordo, A.E. Perello, and P.C. Struik. 2003. Influence of nitrogen supply on the susceptibility of wheat to Septoria tritici. J. Phytopathol. 151:283-289.

Thomidis, T. and K. Elena. 2001. Effects of metalaxyl, fosetyl-Al, dimethomorph and cymoxanil on Phytophthora cactorum of peach tree. J. Phytopathol. 149:97101 .

Tidball, C.J. and R.G. Linderman. 1990. Phytophthora root and stem rot of apple rootstocks from stool beds. Plant Dis. 74:141-146.

Upstone, M.E. 1978. Phytophthora syringae fruit rot of apples. Plant Pathol. 27:24-30.

Varadarajan, S., A.S. Karthikeyan, P.D. Matilda, and K.G. Raghothama. 2002. Phosphite, an analog of phosphate, suppresses the coordinated expression of genes under phosphate starvation. Plant Physiol. 129:1231-1240.

Walker, G.E. 1989. Phytotoxicity in mandarins caused by phosphorus acid. Austral. Plant Pathol. 18:57-59. 


\section{Research Reports}

Wicks, T.J. and B. Hall. 1988. Preliminary evaluation of phosphorous acid, fosetyl-Al and metalaxyl for controlling Phytophthora cambivora on almond and cherry. Crop Prot. 7:314-318.

Wilkinson, C.J., J.M. Holmes, B. Dell, K.M. Tynan, J.A. McComb, B.L. Shearer, I.J. Colquhoun, and G.E.S.J. Hardy.
2001. Effect of phosphate on in planta zoospore production of Phytophthora cinnamomi. Plant Pathol. 50:587-593.

Wormald, H. 1919. A Phytophthora rot of pears and apples. Ann. Appl. Biol. 6:89100 .
Yemm, E.W. and E.C. Cocking. 1955. The determination of amino acid with ninhydrin. Analyst (Lond.) 80:209213.

Young, R.A. and J.A. Milbrath. 1959. A stem canker of fruit tree nursery stock caused by Phytophthora syringae. Phytopathology 49:114-115. 